\title{
ED-XRF analysis of the mediaeval copper-based door in Monte Sant'Angelo (Southern Italy)
}

\author{
Alessandro Buccolieri ${ }^{1}$ (D) Alfredo Castellano ${ }^{1}$ (D) $\cdot$ Vito Nicola lacobellis $^{2} \cdot$ Fabio Paladini $^{1} \cdot$ Giovanni Buccolieri $^{1}$ (D)
}

Received: 12 January 2021 / Accepted: 1 April 2021 / Published online: 14 May 2021

(C) The Author(s) 2021

\begin{abstract}
This work regards the analysis of a copper-based door (dated 1076 AD) located at the entrance to the sanctuary of Monte Sant'Angelo (Southern Italy) by using a non-destructive technique and in situ chemical analysis. The door does not show serious corrosive phenomena and presents several types of decorative elements such as two inlays (of silver and copper colour) and three engravings (of red, black and green colour). A portable energy dispersive X-ray fluorescence (ED-XRF) spectrometer was used in order to evaluate the chemical composition of the door and of the decorations that adorn the artefact. No sampling or sample preparation was required before the measurements. Preliminary analysis on the materials that make up the door revealed that the panels and the frame of the two sashes are made of the same alloy, while the nails and the handles have a different composition.
\end{abstract}

Keywords ED-XRF $\cdot$ Portable apparatus $\cdot$ Mediaeval copper-based door $\cdot$ Inlay $\cdot$ Niello

\section{Introduction}

In Europe, there are less than thirty specimens of mediaeval copper-based doors (Frazer 1973; Alessandrini et al. 1979; Weinryb 2016), all made in the early years of the eleventh century and the mid-thirteenth century, that have survived up to the present day. In the transition from the ancient world to the Middle Ages, only a few examples of bronze doors have survived. The action of atmospheric agents, the plundering of the precious elements that decorated these doors or the reuse of the materials that composed them are among the most common causes that led to the disappearance of a large part of the doors produced in the classical period. Very few of these doors have survived to the present day. Most of them date back to the last centuries of the Western Roman Empire and are characterised by the simplicity of the decorative motifs, plant or animal that adorn them. Clear examples of this type of door are the monumental bronze doors of Hadrian's Pantheon, the door of the temple of the Divine Romulus or the valves

Alessandro Buccolieri

alessandro.buccolieri@unisalento.it

1 Dipartimento di Matematica e Fisica "Ennio De Giorgio", Università del Salento, via per Arnesano, Lecce, Italy

2 Polo Museale della Puglia, via Pier l'Eremita 25, /b Bari, Italy with acanthus spirals of the Curia Julia. Throughout the Middle Ages, bronze was one of the most widely used materials, not only for its value but also for its references to the Imperial era. Together with the practice of reusing ancient doors, the Middle Ages saw a renewed production of bronze doors clearly inspired by the ancient ones from the Roman era.

The bronze doors were decorated with scenes from the Bible (Banti 1999), and then depictions of the life of Jesus became increasingly common. This trend was confirmed in the period of Charlemagne's Renovatio Imperii. The Pax Imperiale triggered a period of renaissance in the decorative arts, especially in the Germanic regions, which led to the production over the following centuries of numerous bronze doors inspired by the typical manufacture of the Roman Imperial age. Clear examples of this kind of doors are those in Mainz Cathedral (ca 1009 AD) and Hildesheim Cathedral (1015 AD), the latter dating from the Ottonian period but clearly inspired by the splendour of the Carolingian Empire (Laging 1967). The massive production of doors in Germany was encouraged by innovations in metal casting techniques which made German craftsmen appreciated throughout Europe. For example, the door of Gniezno cathedral in Poland and the door of Novgorod cathedral in Russia, both dating from the eleventh century, were probably made by artisans trained in German workshops.

From the year 1000 onwards, the manufacture of bronze doors was not exclusive of the West. The doors manufactured 
in Constantinople and exported from there to Italy attest the existence of a well-established Byzantine casting tradition. In the history of cultural and artistic relations between Byzantium and Italy, a milestone is marked by the creation of the bronze door for the Amalfi cathedral (1060 AD), which opens a long and well-known series of similar artefacts made for churches in the peninsula. In addition to the Amalfi door, seven bronze doors were transported to Italy over a period of almost 50 years.

Most of these doors are located in central-southern Italy: in Monte Cassino in the abbey church (1066 AD) (Bloch 1987; Kleinbauer 1976), in Rome in S. Paul's outside the Walls (1070 AD) (Ristovska 2017), in Monte Sant'Angelo in the sanctuary of S. Michele Arcangelo (1076 AD), in Atrani in S. Salvatore de Birecto (1087 AD), in Salerno in the cathedral (1085 AD), in Benevento (1150-1151 AD), in Canosa di Puglia (1111-1118 AD), in Troia (1119-1127 AD) and in Monreale (1140 AD). Exceptions are the door of $\mathrm{S}$. Clemente (ca 1080 AD) and the central door (c. 1112 $\mathrm{AD}$ ) in the atrium of S. Marco in Venice.

Unlike western bronze doors, such as the one in Hildesheim, Byzantine doors are made of copper-based alloy or orichalc and not bronze. Nevertheless, these doors are known as "bronze door" probably because, with the passage of time, brass turns green like bronze.

From a structural point of view, Byzantine doors are made of small modular units of ternary copper-lead-zinc alloy with low concentration of tin, fixed by nails to a wooden core. This system made it possible to make doors that were not only lighter and more manageable but, above all, easily transportable in the case of distant destinations. According to Angelucci, the most suitable production process for Byzantine doors was not the "lost wax" technique, more congenial to works in relief, but the "sand" or "bracket" technique (Angelucci 1997; Matthiae 1971).

Although designed with an industrial mentality, these doors were decorated with refined goldsmith's work, the "formelle", made using the techniques of inlay and niello (Moss 1953; Newman et al. 1982; Oddy et al. 1983). From an iconographic point of view, the Byzantine doors are characterised by the Deesis, and they are based on the Johannine concept of Christ Ianua Coeli and were therefore, as Frazer stated, a kind of "door to the paradise" for the faithful, through which they could achieve forgiveness and salvation (Frazer 1973). Depending on the door, the central panels contain representations of Christ, the Virgin Mary, the Archangels or the titular saints of the church. The role attributed to them is that of intercessors with God for the entry of the faithful into the Kingdom of Heaven.

The doors manufactured in Constantinople and exported from there to Italy clearly attest to the existence of a deeprooted Byzantine casting tradition. Unfortunately, the complete loss of older pieces does not allow us to understand how the sophisticated production methods attested in the eleventh century were formulated.

Many of these doors are located in Southern Italy, and among them, five can be observed in Apulia. In particular, one (dated 1076 AD) is at sanctuary of Monte Sant'Angelo in Monte Sant'Angelo, one (made in the eleventh century) is at Mausoleum of Boemondo d'Altavilla in Canosa di Puglia and one (1111-1118 AD) is at the Cathedral of Trani. This door, recently restored, is now kept inside the temple. The remaining two doors are located at the Cathedral of Troia, and they were both made by Oderisio of Benevento. The main door was commissioned by bishop Guglielmo II in 1119 AD, and the secondary door, located in the southern side of the Cathedral, is dated 1127 AD.

We would like to emphasise that, to the best of our knowledge, there is very little scientific research reporting analysis regarding the composition of mediaeval copper-based doors (Matthiae 1971; Angelucci et al. 2004; Cesareo et al. 1973; Chiavari et al. 2015; Daniec 1966; Daniec 1991; Iacobini 2009; Osticioli et al. 2009).

Several analytical techniques have been employed in recent years for the study of artefacts of historical-artistic interest in order to help art historians, archaeologists, restorers and conservators to learn more regarding ancient artefacts, their state of conservation, their degradation mechanisms and their provenance (Brunetti et al. 2014; Chiari et al. 2016; Potts and West 2008; Sianoudis et al. 2010; Uda et al. 2005; Van Grieken and Worobiec 2011).

Moreover, when possible, the researchers preferred to use non-invasive and in situ techniques such as energy dispersive $\mathrm{X}$-ray fluorescence (ED-XRF). In fact, this analytical method is portable, non-destructive, fast and relatively simple and does not require any sample preparation.

The aim of the present work is the analysis of the copper-based door of the sanctuary of Monte Sant'Angelo by using portable energy dispersive X-ray fluorescence in order to gain in-depth knowledge about the patinas of the alloy and the polychrome decorations (inlay and niello). The inlay is a metalworking technique used since ancient times to obtain a polychrome decoration by inlaying metals of different colours on the surface of a metal artefact. This method was widely used in Byzantine art but was also found in Egyptian art. In inlay, the trace of the desidered design is carved with a chisel on a metal object. The obtained grooves are filled with precious metal wires of a different colour from that of the object on which the engraving was made. In order to secure the metal inserts, they are beaten with a hammer (Kleinbauer 1976; Photos et al. 1994).

These experimental results may be used in the future by restorers and other researchers as a comparison when all the Byzantine doors will be restored. 


\section{Material and methods}

\section{Description of the door analysed}

The sanctuary of Monte Sant'Angelo is a Catholic sanctuary located on Monte Gargano in the province of Foggia (Northern Apulia, Italy). It is the oldest shrine in Western Europe dedicated to the Arcangelo Michele and has been an important pilgrimage site since the early Middle Ages. In 2011 AD, it became a UNESCO World Heritage Site.

The mediaeval door of this sanctuary was manufactured in Constantinople in 1076 AD by the craftsman Symon of Syria. It was donated by Pantaleone d'Amalfi at the behest of the Archbishop of Siponto, Gerardo. The door consists of two rectangular sashes $3.07 \mathrm{~m}$ high. The left leaf is $97.7 \mathrm{~cm}$ wide, while the right leaf is $93.7 \mathrm{~cm}$ wide. The two sashes of the door are made of a wooden framework with horizontal and vertical bands. Twenty-four copper-based panels are fixed to the door and have been attached to the frame using round-headed metal pegs. The precious door of the entrance to the sanctuary in Monte Sant'Angelo, the most important site of the Archangel in Western Europe, is a typical example of Byzantine art, as evidenced by the numerous engravings, inlays and decorations, which enrich the whole artefact. All the Byzantine doors, except that of Monte Sant'Angelo, have leaf crosses fused apart and applied with studs.

The figurative panels describe episodes taken from the Old and New Testament of the Bible and representations of the apparition of the Arcangelo Michele in the Gargano. They are characterised by polychrome decorations, inlay and niello (Iacobini 2009; Photos 1994). Moreover, a panel is engraved with two inscriptions dedicated to Pantaleone d'Amalfi. An epigraph on the left leaf of the door "Rogo et adiuro rèctores sancti Angeli Michaelis ut semel in anno detergere faciatis has portas sicuti nos nunc ostendere fecimus ut sint semper lucide et clare" (I pray and implore the Rectors of sanctuary of S. Michele Arcangelo that they must cleaned one time a year these doors in a way in which now we have shown so that they will always be splendid and bright) shows an advice of the cleanness of the manufact. This suggests that the Byzantine doors did not travel fixed on a wooden support, but would have been assembled in Italy, almost certainly under the supervision of a master from Constantinople, who also would have demonstrated how to polish the precious artefact. Fig. S1 shows a $1763 \mathrm{AD}$ engraving of the studied door, which is kept in the library of sanctuary of San Marco in Lamis (Apulia, Italy).

Figure 1 shows a picture of the analysed door, and it also reports the measuring points. Figure 2 shows four details of both the inlays and the decorations.

\section{Instruments and operating methodology}

The analysis was performed by using an energy dispersive X-ray fluorescence (ED-XRF) portable instrument

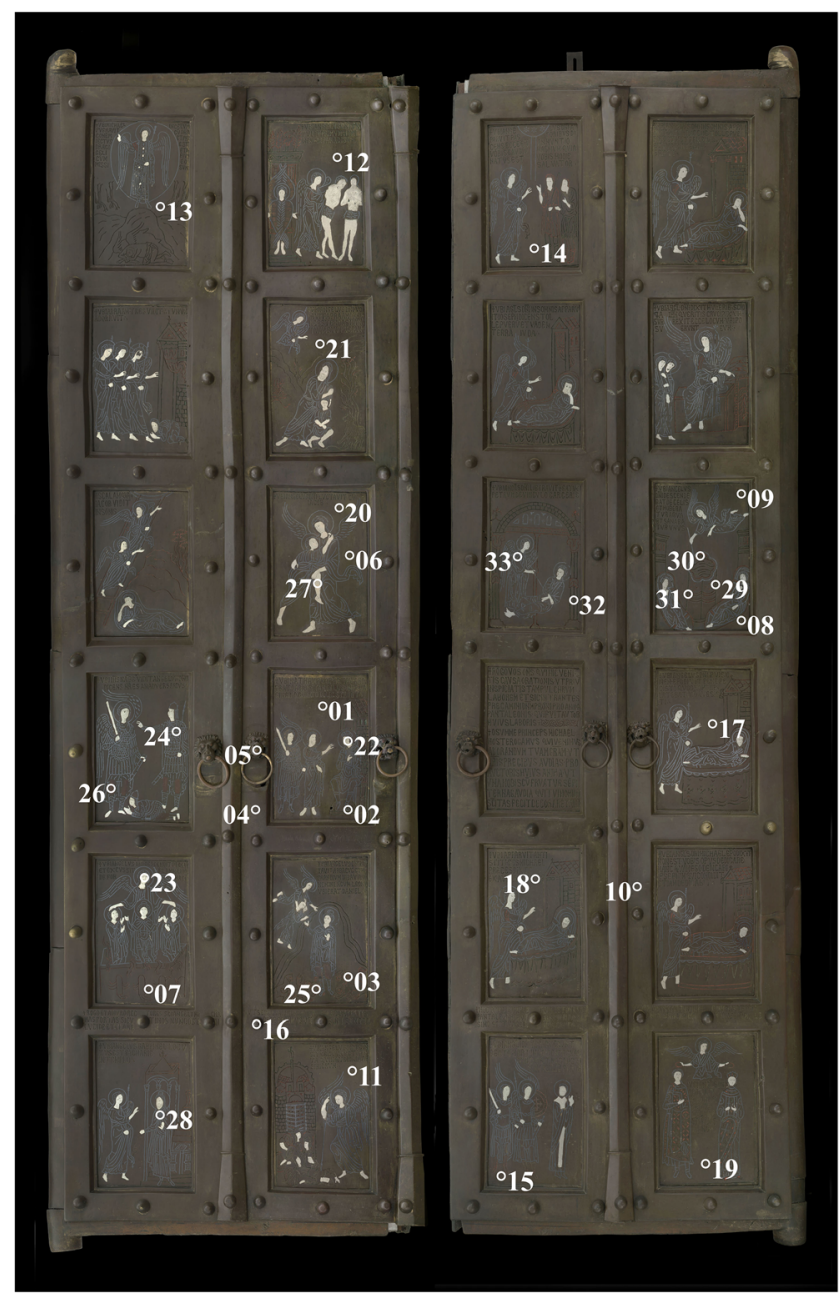

Fig. 1 A picture of the mediaeval door of the Sanctuary of Monte Sant'Angelo (Foggia, Apulia, Italy) with the measurement points of the analysis performed

designed at the University of Salento (Buccolieri et al. 2015; Buccolieri et al. 2018).

It is composed by an X-ray tube produced by MOXTEK with a Pd-anode operating at $1-40 \mathrm{kV}$ of voltage and $0-100 \mu \mathrm{A}$ of current; a Si-PIN detector produced by AMPTEK model XR_100CR; thermoelectrically cooled, with a beryllium window of $25 \mu \mathrm{m}$ and a resolution of $150 \mathrm{eV}$ at $5.9 \mathrm{keV}$; and a pocket multi-channel analyser produced by AMPTEK model MCA8000A interfaced with a laptop. The diameter of the Xray beam is an ellipse whose axes are equal to $2 \mathrm{~mm}$ and $3 \mathrm{~mm}$.

$\mathrm{Fe}, \mathrm{Cu}, \mathrm{Zn}$ and $\mathrm{Pb}$ were quantitatively determined at high energy: $20 \mathrm{kV}$ of voltage, $3 \mu \mathrm{A}$ of current with an acquisition time of $60 \mathrm{~s}$. Ag, S and $\mathrm{Sn}$ were determined at low energy: $6 \mathrm{kV}$ of voltage, $40 \mu \mathrm{A}$ of current with an acquisition time of $60 \mathrm{~s}$.

The calibration was carried out by analysing five standards consisting of $\mathrm{Fe}, \mathrm{Zn}, \mathrm{Ag}, \mathrm{Pb}_{3} \mathrm{O}_{4}, \mathrm{SnO}_{2}, \mathrm{CuO}, \mathrm{CuCO}_{3}, \mathrm{CaCO}_{3}$ and $\mathrm{Cu} / \mathrm{Sn}(80 / 20 \% \mathrm{w} / \mathrm{w})$ in different ratios. The 

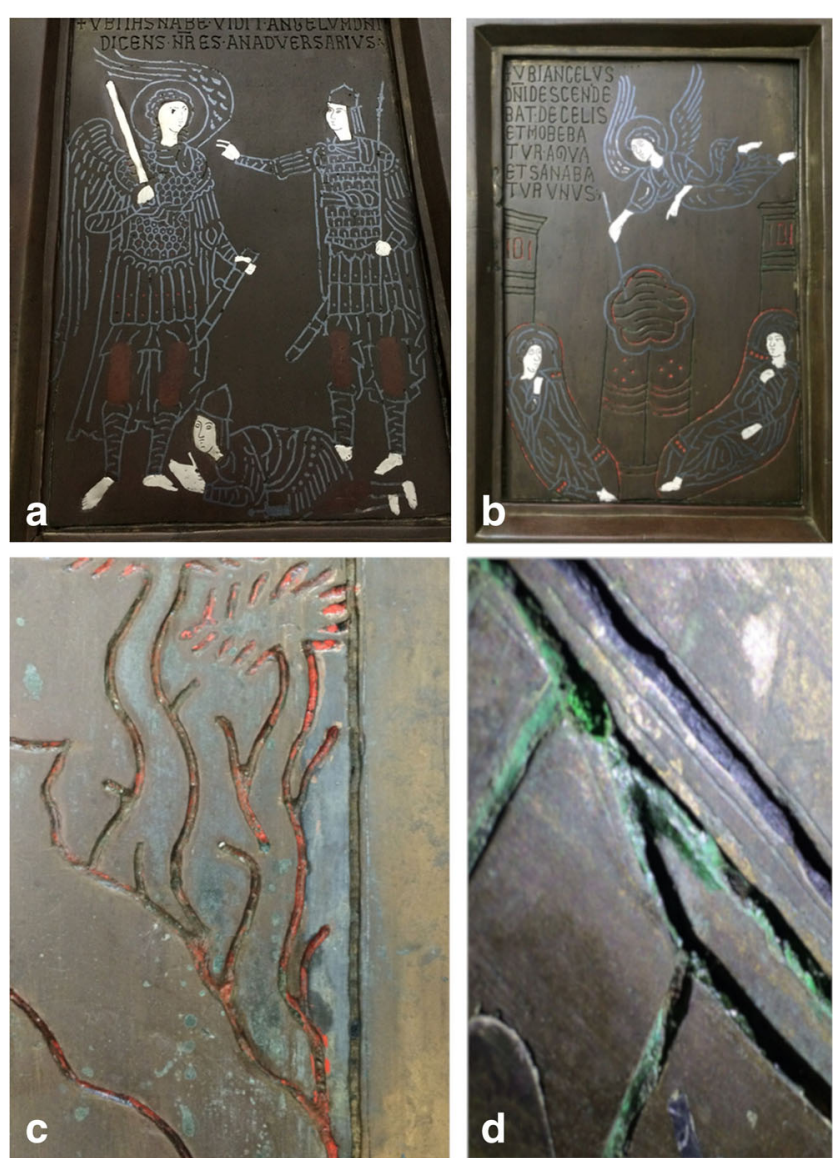

Fig. 2 Some photos of silver inlay, copper inlay and niello (a); silver inlay, red and green engravings and niello (b); red engraving (c); and green decorations $(\mathbf{d})$

concentration of each standard was chosen according to the composition of both the alloy and inlay.

All chemical compounds were analytical grade and purchased from Sigma-Aldrich ${ }^{\circledR}$ except the $\mathrm{Cu} / \mathrm{Sn}(80 / 20 \%$ w/w) standard which was purchased from Goodfellow ${ }^{\circledR}$.

Each standard was prepared by mixing the compounds in different weight percentages. In particular, the chemical compounds were weighted using an analytical balance KERN model ABT 100-5M, subsequently mixed and homogenised in an agate mortar for $10 \mathrm{~min}$ and finally compressed at 200 bar for $10 \mathrm{~min}$. The homogeneity of elements in the standard meets the requirements for the ED-XRF quantitative analysis. Moreover, the samples analysed are assumed to have "infinite thickness", and the quantitative results are expressed in terms of weight percentage ( $\% \mathrm{wt})$. Table 1 shows the quantitative chemical composition of the analysed standards.

\section{Results and discussion}

The use of ED-XRF technique made possible to obtain the composition of the alloy, of the inlays (silver and copper colour) and of the decorations. Table 2 summarises the results of
Table 1 Chemical composition of the standards used for calibration in ED-XRF analysis

\begin{tabular}{llllll}
\hline Standard & $\begin{array}{l}\mathrm{Fe} \\
(\% \mathrm{wt})\end{array}$ & $\mathrm{Cu}$ & $\mathrm{Zn}$ & $\mathrm{Sn}$ & $\mathrm{Pb}$ \\
\hline 1 & 0.5 & 73.5 & 4.8 & 2.2 & 12.5 \\
2 & 1.1 & 65.2 & 7.5 & 4.9 & 8.2 \\
3 & 2.0 & 58.5 & 12.4 & 8.3 & 5.8 \\
4 & 2.8 & 51.4 & 18.5 & 10.8 & 3.6 \\
5 & 3.3 & 48.7 & 21.3 & 11.9 & 2.5 \\
st. dev. & 0.2 & 0.5 & 0.5 & 0.3 & 0.5 \\
\hline
\end{tabular}

the quantitative chemical composition of the analysed samples. The standard deviation for iron, copper, zinc, tin and lead is estimated to be $0.2,0.5,0.5,0.3$ and $0.5 \% \mathrm{wt}$, respectively.

The material used for the realisation of the panels is a copper-zinc-lead alloy, which is mainly made up of copper, zinc and lead with traces of iron and tin. This alloy is consistently present in all panels of the two sashes of the door. In addition, the door frame (sample n. 4 and sample n. 10) also has a composition similar to that of the panels.

On the contrary, the doorknob on the left side with the shape of a lion's snout (sample n. 5) and the nail head (sample

Table 2 Brief description of the analysed samples and their composition obtained by using ED-XRF

\begin{tabular}{|c|c|c|c|c|c|c|}
\hline Measuring point & Description & $\begin{array}{l}\mathrm{Fe} \\
(\%\end{array}$ & $\begin{array}{l}\mathrm{Cu} \\
\text { wt) }\end{array}$ & $\mathrm{Zn}$ & $\mathrm{Sn}$ & $\mathrm{Pb}$ \\
\hline 1 & \multirow[t]{10}{*}{ Alloy, panel left side } & 1.0 & 72.6 & 14.7 & 0.7 & 8.8 \\
\hline 2 & & 1.3 & 71.4 & 14.9 & 1.0 & 9.3 \\
\hline 3 & & 0.5 & 69.8 & 15.6 & 0.7 & 9.2 \\
\hline 6 & & 1.3 & 71.0 & 14.7 & 0.7 & 10.6 \\
\hline 7 & & 1.2 & 69.0 & 12.4 & 1.1 & 10.9 \\
\hline 11 & & 0.6 & 69.1 & 13.2 & $<0.3$ & 13.5 \\
\hline 12 & & 0.5 & 69.8 & 14.8 & $<0.3$ & 11.9 \\
\hline 13 & & 1.1 & 70.8 & 13.9 & $<0.3$ & 11.5 \\
\hline 20 & & 0.6 & 68.6 & 12.3 & $<0.3$ & 14.2 \\
\hline 21 & & 0.8 & 71.6 & 14.7 & $<0.3$ & 10.8 \\
\hline 8 & \multirow[t]{7}{*}{ Alloy, panel right side } & 1.0 & 67.5 & 13,5 & $<0.3$ & 13.6 \\
\hline 9 & & 1.0 & 69.8 & 14.7 & $<0.3$ & 12.9 \\
\hline 14 & & 0.5 & 70.0 & 14.0 & $<0.3$ & 11.1 \\
\hline 15 & & 0.4 & 71.3 & 13.1 & $<0.3$ & 10.4 \\
\hline 17 & & 0.6 & 68.2 & 14.4 & $<0.3$ & 12.7 \\
\hline 18 & & 0.5 & 72.3 & 14.2 & $<0.3$ & 9.0 \\
\hline 19 & & 0.6 & 70.7 & 15.2 & $<0.3$ & 9.3 \\
\hline 4 & Frame, left side & 1.4 & 62.7 & 18.6 & 0.7 & 13.6 \\
\hline 10 & Frame, right side & 1.2 & 71.3 & 14.7 & 0.6 & 11.4 \\
\hline 5 & Doorknob, left side & 1.5 & 61.0 & 16.6 & 3.3 & 15.0 \\
\hline 16 & Nail, left side & 1.0 & 59.4 & 26.0 & 6.1 & 4.6 \\
\hline
\end{tabular}


n. 16) have a different chemical composition. In particular, sample n. 5 has a higher concentration of tin and lead, while sample n. 16 presents a lower content of copper and lead, a higher zinc and tin concentration and a different zinc/copper ratio compared to that of the alloy of the panels. These results do not allow us to establish if the nail head and the doorknob come from the same fusion batch as the panels or if they were replaced subsequently.

To better understand the experimental data obtained, Fig. 3 presents the distribution of zinc, lead and copper for the analysed samples reported, which demonstrates that all samples have similar composition except for samples n. 4, n. 5 and n. 16 .

Table 3 shows a comparison between the composition of the alloy obtained in this work and that of other six Byzantine doors. The chemical composition of the studied door is similar to the other doors, and the alloy can be classified as copper-based. The choice of these concentrations was not fortuitous as this alloy is softer and easier to work than bronze, and therefore, it can be more easily excavated to obtain the grooves that were afterwards to be used for decorations (Matthiae 1971).

The inlay of silver colour (samples n. 22, n. 23 and n. 27) shows the presence of silver and copper as the main elements (Fig. 4a). The absence of zinc shows that the signal of copper does not come from the layer below the plate, and therefore, the inlay is made up of a silver/copper alloy.

In particular, the chemical composition of these inlay is the following: n. 22 (Ag 91.0 $1.0 \% \mathrm{wt} ; \mathrm{Cu} 9.0 \pm 0.5 \% \mathrm{wt})$, n. 23 (Ag 90.0 $\pm 1.0 \%$ wt; $\mathrm{Cu} \mathrm{10.0 \pm 0.5 \%} \mathrm{wt)} \mathrm{and} \mathrm{n.} 27$ (Ag 90.5 $1.0 \%$ wt; $\mathrm{Cu} 9.5 \pm 0.5 \% \mathrm{wt})$. It can be observed that the composition of the three inlays is uniform with average value of silver and copper equal to $90.5 \pm 0.6 \%$ wt and $9.5 \pm 0.3 \%$ wt, respectively. This result confirms that the studied inlay of silver colour was made with the same silver/copper alloy.

Subsequently, it was possible to determine qualitatively the principle, secondary and trace elements of both the inlay of copper colour and the engravings (red, black and green). Table 4 summarises the experimental results obtained. The quantitative analysis was not carried out for the decorations since their surface is not homogeneous. The level of surface irregularity on an old artefact can be quite high, and this is a critical point that must be carefully considered (Letardi et al. 2016).

For the decorations in red, black (niello) and green, it is not possible to provide quantitative results considering the dimensions of the incisions (less than the dimension of the X-ray beam used).

The inlay of copper colour (sample n. 26) is made exclusively of copper (Fig. 4b).

The black incisions (samples n. 24, n. 28 and n. 33) show the presence of copper and sulphur as main elements, zinc and silver as secondary elements and lead as element in trace. These results confirm the use of niello technique for the realisation of these black incisions. In fact, this method employs a black mixture composed of $\mathrm{Ag}_{2} \mathrm{~S}, \mathrm{Cu}_{2} \mathrm{~S}$ and $\mathrm{PbS}$ to cover the incisions in order to obtain the blackish pigmentation.

The ED-XRF spectrum obtained on the red incisions (samples n. 25 and n. 30) shows the elements of the alloy (copper, zinc and lead) but, also, the signal of mercury (Fig. 4c) and sulphur as secondary elements and calcium in trace. This might suggest that cinnabar $(\mathrm{HgS})$ was used for the creation of this decoration. Moreover, calcium is probably derived from deposits of calcium carbonate.

The green engravings (samples n. 29, n. 31 and n. 32) show copper as the main element, in addition to zinc and arsenic as secondary elements (Fig. 4d). Arsenic could derive from some product used in restoration works (probably copper(II) acetoarsenite, $\left.\mathrm{Cu}\left(\mathrm{C}_{2} \mathrm{H}_{3} \mathrm{O}_{2}\right)_{2} \cdot 3 \mathrm{Cu}\left(\mathrm{AsO}_{2}\right)_{2}\right)$. This result confirms that the door of Monte Sant'Angelo is the only one from Constantinople to have a chromatic finish of green colour (Iacobini 2009).

In particular, with regard to these engravings, it is important to point out that they are enamel inlays.
Fig. 3 Distribution of zinc, lead and copper for the analysed samples. On the right, a magnification of the cluster is reported

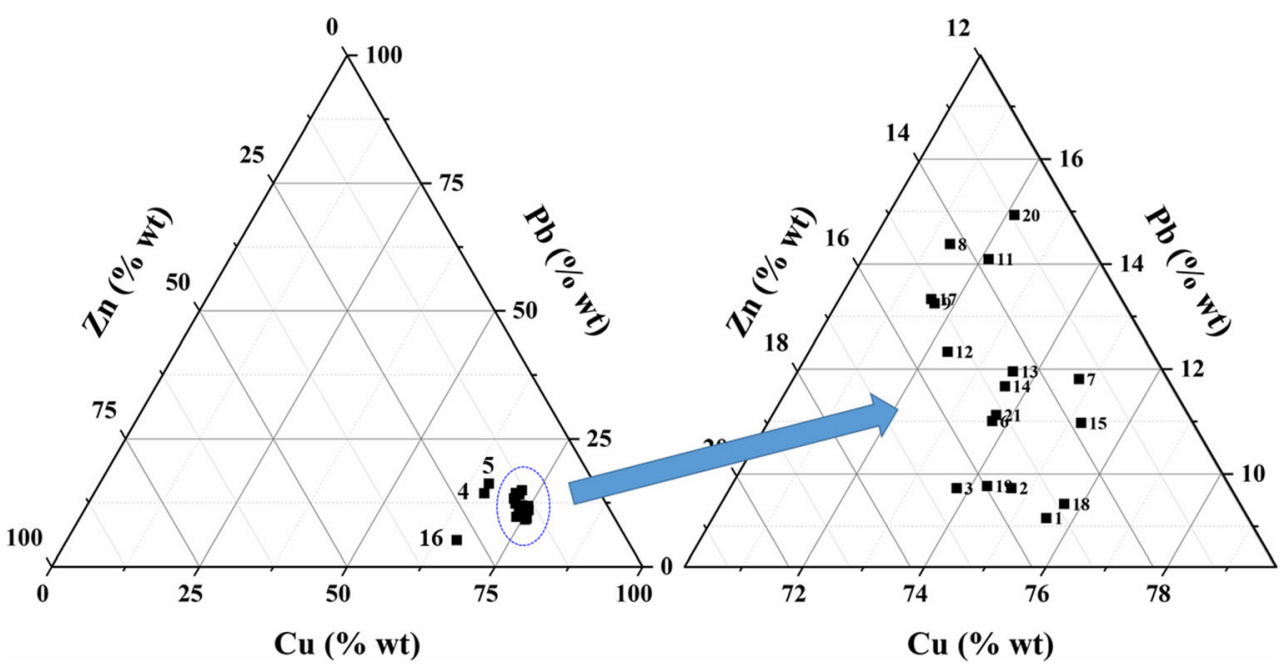


Table 3 Comparison between the composition of alloy obtained in this work and that of other Byzantine doors

\begin{tabular}{llllll}
\hline Byzantine door & $\begin{array}{l}\mathrm{Cu} \\
(\% \mathrm{wt})\end{array}$ & $\mathrm{Pb}$ & $\mathrm{Zn}$ & $\mathrm{Sn}$ & Reference \\
\hline Amalfi (1060 AD) & 62 & 19 & 17 & trace & Banti (1999) \\
Monte Cassino (1066 AD) & 80 & 3 & 10 & 7 & Matthiae (1971) \\
Rome, S. Paul's outside the Walls (1070 AD) & 73.5 & 8.48 & 17.9 & 0.12 & Matthiae (1971) \\
Monte Sant'Angelo (1076 AD) & 70.2 & 11.2 & 14.2 & 0.8 & This work \\
Venice, S. Clemente (1080 AD) & 72.4 & 8.6 & 16.8 & 2.2 & Matthiae (1971) \\
Salerno (1085 AD) & 77 & 11 & 4.5 & 3.5 & Banti (1999) \\
Venice, central door (1112 AD) & 78 & 8 & 9 & 5 & Matthiae (1971) \\
\hline
\end{tabular}

These were found on other doors such as the basilica of St. Paul's outside the Walls in Rome (Frazer 1973; Ristovska 2017) and the central door of Venice (Federici 1969). Moreover, similar decorations were determined on other Byzantine metalwork, such as crowns, chalices and cups frequently with figural imagery (Distelberger et al. 1993; La Niece and Craddock 1993; Woodfin 2017).
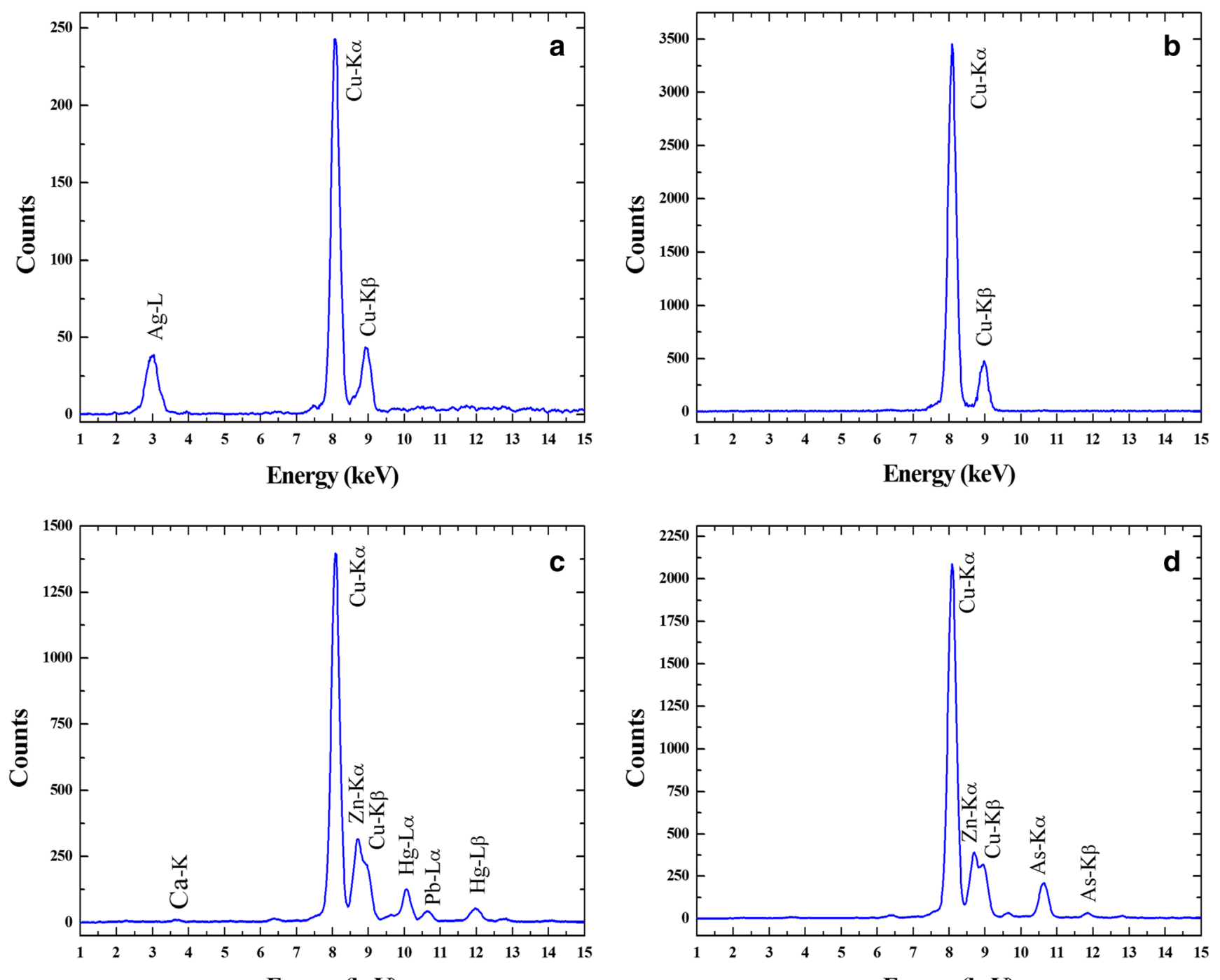

Energy (keV)

Energy (keV)

Fig. 4 ED-XRF spectrum of silver inlay (a), copper inlay (b), red incision (c) and green engravings (d) 
Table 4 Brief description of the analysed engravings and elements qualitatively determined by using ED-XRF

\begin{tabular}{lll}
\hline Measuring point & Description & Determined elements \\
\hline 24 & Black engraving, left side & $\mathrm{S}^{\mathrm{I}}, \mathrm{Cu}^{\mathrm{I}}, \mathrm{Zn}^{\mathrm{II}}, \mathrm{Ag}^{\mathrm{II}}, \mathrm{Pb}^{\mathrm{tr}}$ \\
25 & Red engraving, left side & $\mathrm{Cu}^{\mathrm{I}}, \mathrm{Zn}^{\mathrm{II}}, \mathrm{Hg}^{\mathrm{II}}, \mathrm{S}^{\mathrm{II}}, \mathrm{Ca}^{\mathrm{III}}, \mathrm{Pb}^{\mathrm{tr}}$ \\
26 & Inlay-Cu, left side & $\mathrm{Cu}^{\mathrm{I}}$ \\
28 & Black engraving, left side & $\mathrm{S}^{\mathrm{I}}, \mathrm{Cu}^{\mathrm{I}}, \mathrm{Zn}^{\mathrm{II}}, \mathrm{Ag}^{\mathrm{II}}, \mathrm{Pb}^{\mathrm{tr}}$ \\
29 & Green engraving, right side & $\mathrm{Cu}^{\mathrm{I}}, \mathrm{Zn}^{\mathrm{II}}, \mathrm{As}^{\mathrm{II}}$ \\
30 & Red engraving, right side & $\mathrm{Cu}^{\mathrm{I}}, \mathrm{Zn}^{\mathrm{II}}, \mathrm{Hg}^{\mathrm{II}}, \mathrm{S}^{\mathrm{II}}, \mathrm{Ca}^{\mathrm{tr}}, \mathrm{Pb}^{\mathrm{tr}}$ \\
31 & Green engraving, right side & $\mathrm{Cu}^{\mathrm{I}}, \mathrm{Zn}^{\mathrm{II}}, \mathrm{As}^{\mathrm{II}}$ \\
32 & Green engraving, right side & $\mathrm{Cu}^{\mathrm{I}}, \mathrm{Zn}^{\mathrm{II}}, \mathrm{As}^{\mathrm{II}}$ \\
33 & Black engraving, right side & $\mathrm{S}^{\mathrm{I}}, \mathrm{Cu}^{\mathrm{I}}, \mathrm{Zn}^{\mathrm{II}}, \mathrm{Ag}^{\mathrm{II}}, \mathrm{Pb}^{\mathrm{tr}}$ \\
\hline
\end{tabular}

${ }^{\text {I }}$ main element; ${ }^{\text {II }}$ secondary element; ${ }^{\text {tr }}$ element presents in trace

\section{Conclusions}

The mediaeval copper-based door of the sanctuary of Monte Sant'Angelo dedicated to San Michele is mainly made up of a ternary alloy of copper, zinc and lead with very low concentration of tin.

The chemical composition of the panels is similar, suggesting that they have not been replaced over the years. In particular, the studied door was manufactured using a similar alloy with the other seven Byzantine doors made in Constantinople and sent to Italy between 1060 and 1110 . On the contrary, the alloy that was used for the manufacture of the nails and the doorknob has a different chemical composition.

Moreover, the investigated door is characterised by a great number of inlays of silver and copper colour and by red, black and green engravings. Regarding the engravings, the red ones are also present on the door of Atrani dedicated to San Salvatore and on the central door of Venice dedicated to San Marco. They were made using cinnabar, a mineral consisting of mercury sulphide. In the case of the black engravings, analyses have shown that they were made using niello, a mixture of metallic sulphides. In the specific case of Monte Sant'Angelo, niello is composed of silver sulphide, copper sulphide and lead sulphide. The green pigment is present only on the studied door. It is almost certain that the specific green pigment is not part of the original decoration, but was most probably added during a restoration carried out between the nineteenth and twentieth centuries.

In conclusion, the portable ED-XRF instrument has allowed the non-destructive and in situ characterisation of the patinas of the alloy and of the numerous decorations. We would like to highlight that in literature, up to nowadays, there are a very limited number of analytical projects regarding the analysis of the chemical composition of mediaeval copper-based doors. Therefore, the experimental results obtained may have a considerable archaeometric impact as they could be used in the future by other mediaeval door scholars.
Supplementary Information The online version contains supplementary material available at https://doi.org/10.1007/s12520-021-01336-x.

Acknowledgements The authors thank Massimo Luggeri (Dipartimento di Scienze e Tecnologie Biologiche e Ambientali, Università del Salento, Italy) who has contributed to improving the quality of the figures.

Funding Open access funding provided by Università del Salento within the CRUI-CARE Agreement.

\section{Declarations}

All authors declare that they have participated in the paper to take public responsibility for the content, including participation in the design, analysis, writing and revision of the manuscript. Moreover, all authors certify that this material has not been published in any other publication.

Conflict of interest The authors declare no competing interests.

Open Access This article is licensed under a Creative Commons Attribution 4.0 International License, which permits use, sharing, adaptation, distribution and reproduction in any medium or format, as long as you give appropriate credit to the original author(s) and the source, provide a link to the Creative Commons licence, and indicate if changes were made. The images or other third party material in this article are included in the article's Creative Commons licence, unless indicated otherwise in a credit line to the material. If material is not included in the article's Creative Commons licence and your intended use is not permitted by statutory regulation or exceeds the permitted use, you will need to obtain permission directly from the copyright holder. To view a copy of this licence, visit http://creativecommons.org/licenses/by/4.0/.

\section{References}

Alessandrini G, Dassù G, Pedeferri P, Re G (1979) On the conservation of the baptistery doors in Florence. Stud Conserv 24:108-124. https://doi.org/10.1179/sic.1979.013

Angelucci S (1997) Il rapporto tra materia, tecnica e forma nelle porte bizantine d'Italia, in Storia dell'arte marciana: sculture, tesoro, arazzi, Atti del convegno internazionale di studi (Venezia 11-14 ottobre 1994), a cura di R. Polacco, Venezia, pp 247-260 
Angelucci S, Diana M, Ferretti M et al (2004) The Byzantine door in the Basilica of St. Paul out of the Walls in Rome: compositional study of the alloys and interpretation of the results in view of its restoration. In: McLeod ID, Theile JM, Degrigny C (eds) Metal 2001: proceedings of the international conference on metals conservation, Actas del congreso internacional sobre la conservacion de metales: Santiago, Chile 2-6 April 2001. Western Australian Museum, Santiago, Chile, pp 104-111

Banti O (1999) Porta di Bonanno nel Duomo di Pisa e le porte bronzee medioevali europee. Opera della Primaziale Pisana. Editore Bandecchi \& Vivaldi, p 326

Bloch H (1987) Origin and Fate of the Bronze Doors of Abbot Desiderius of Monte Cassino. Studies on art and archeology in honor of ErnstKitzinger on his seventy-fifth birthday. Dumbarton Oaks Papers, Trustees for Harvard University. 41:89-102

Brunetti A, Golosio B, Melis MG, Mura S (2014) A high-quality multilayer structure characterization method based on X-ray fluorescence and Monte Carlo simulation. Appl Phys A Mater Sci Process 118: 497-504. https://doi.org/10.1007/s00339-014-8838-9

Buccolieri G, Buccolieri A, Donati P, Marabelli M, Castellano A (2015) Portable EDXRF investigation of the patinas on the Riace Bronzes. Nucl Instruments Methods Phys Res Sect B Beam Interact with Mater Atoms 343:101-109. https://doi.org/10.1016/j.nimb.2014. 11.064

Buccolieri A, Degl'Innocenti E, Cesareo R et al (2018) Non-invasive insitu analysis of a wreath of gold leaves from the National Archaeological Museum of Taranto, Italy. Meas J Int Meas Confed 126:164-167. https://doi.org/10.1016/j.measurement.2018. 05.063

Cesareo R, Sciuti S, Marabelli M (1973) Non-destructive analysis of ancient bronzes. Stud Conserv 18:64-80. https://doi.org/10.1179/ sic. 1973.006

Chiari G, Sarrazin P, Heginbotham A (2016) Non-conventional applications of a noninvasive portable X-ray diffraction/fluorescence instrument. Appl Phys A Mater Sci Process 122:990. https://doi.org/10. 1007/s00339-016-0521-x

Chiavari C, Bernardi E, Balbo A, Monticelli C, Raffo S, Bignozzi MC, Martini C (2015) Atmospheric corrosion of fire-gilded bronze: Corrosion and corrosion protection during accelerated ageing tests. Corros Sci 100:435-447. https://doi.org/10.1016/j.corsci.2015.08. 013

Daniec JI (1966) The bronze door of the Gniezno cathedral in Poland. Pol Rev 11:10-65

Daniec JI (1991) An enigma: the medieval bronze church door of plock in the cathedral of Novgorod. Pol Rev 36:21

Distelberger R, Luchs A, Verdier P, Wilson TH (1993) Western decorative arts, part I, Medieval, renaissance, and historicizing styles including metalwork, enamels, and ceramics. National Gallery of Art, Washington Cambridge University Press, p 333

Federici V (1969) Il restauro delle porte bizantine di San Marco, pp. 2334. in B. Forlati, F. Forlati, Le porte bizantine di San Marco, Venezia

Frazer ME (1973) Church doors and the gates of Paradise: Byzantine bronze doors in Italy. Dumbart Oaks Papers 27:145-148. https:// doi.org/10.2307/1291338

Iacobini A (2009) Le porte bronzee bizantine in Italia: arte e tecnologia nel Mediterraneo medievale. Campisano Editore, p 600
Kleinbauer WE (1976) A Byzantine revival: the inlaid bronze doors of Constantinople. Archaeology. 29(1):16-29

La Niece S, Craddock P (1993) Metal plating and patination. Cultural, Technical and Historical Developments. Butterworth-Heinemann Ltd, p 256

Laging DW (1967) The methods used in making the bronze doors of Augsburg cathedral. The Art Bulletin 49(2):129-136

Letardi P, Salvadori B, Galeotti M, Cagnini A, Porcinai S, Santagostino Barbone A, Sansonetti A (2016) An in situ multi-analytical approach in the restoration of bronze artefacts. Microchem J 125: 151-158. https://doi.org/10.1016/j.microc.2015.11.018

Matthiae G (1971) Le porte bronzee bizantine in Italia. Officina edizioni, Roma, p 113

Moss AA (1953) Niello. A. A. Moss. Studies in Conservation 1(2):49-62

Newman R, Dennis JR, Farrell E (1982) A technical note on niello. J Am Inst Conserv 21:80-85. https://doi.org/10.1179/ 019713682806028568

Oddy A, Bimson M, La Niece S (1983) The composition of niello decoration on gold, silver and bronze in the antique and mediaeval periods. Stud Conserv 28:29-35. https://doi.org/10.1179/sic.1983. 28.1.29

Osticioli I, Mendes NFC, Porcinai S, Cagnini A, Castellucci E (2009) Spectroscopic analysis of works of art using a single LIBS and pulsed Raman setup. Anal Bioanal Chem 394:1033-1041. https:// doi.org/10.1007/s00216-009-2653-8

Photos E, Jones RE, Papadopoulos T (1994) The black inlay decoration on a Mycenaean bronze dagger. Archaeometry 36:267-275. https:// doi.org/10.1111/j.1475-4754.1994.tb00969.x

Potts PJ, West M (eds) (2008) Portable X-ray fluorescence spectrometry. Royal Society of Chemistry, Cambridge

Ristovska N (2017) Medieval Byzantine in the context of artistic interchange between East and West: the illuminating example of the inlaid brass door at Saint Paul outside the Wall in Rome. In: Papacostas T, Parani M (eds) Discipuli dona ferentes: glimpses of Byzantium in honour of Marlia Mundell Mango. Brepols Publishers, pp 363-445. https://doi.org/10.1484/M.SBHC-EB.5. 113352

Sianoudis I, Drakaki E, Hein A (2010) Educational x-ray experiments and XRF measurements with a portable setup adapted for the characterization of cultural heritage objects. Eur J Phys 31:419-431. https:// doi.org/10.1088/0143-0807/31/3/001

Uda M, Demortier G, Nakai I (eds) (2005) X-rays for Archaeology. Springer-Verlag, Berlin/Heidelberg

Van Grieken R, Worobiec A (2011) X-ray spectrometry for preventive conservation of cultural heritage. Pramana - J Phys 76:191-200. https://doi.org/10.1007/s12043-011-0041-3

Weinryb I (2016) The bronze object in the Middle Ages. Cambridge University Press, Cambridge

Woodfin WT (2017) The mock turtle's tears: ersatz enamel and the hierarchy of media in Pseudo-Kodinos. In Byzantine and Modern Greek Studies 41(1). Cambridge University Press. pp. 55-80.

Publisher's note Springer Nature remains neutral with regard to jurisdictional claims in published maps and institutional affiliations. 